\title{
Nobelprijs voor Onderwijs
}

\author{
Citation for published version (APA):
}

Bos, G. M. J. (2012). Nobelprijs voor Onderwijs. Maastricht University. https://doi.org/10.26481/spe.20120607gb

Document status and date:

Published: 07/06/2012

DOI:

10.26481/spe.20120607gb

Document Version:

Publisher's PDF, also known as Version of record

\section{Please check the document version of this publication:}

- A submitted manuscript is the version of the article upon submission and before peer-review. There can be important differences between the submitted version and the official published version of record.

People interested in the research are advised to contact the author for the final version of the publication, or visit the DOI to the publisher's website.

- The final author version and the galley proof are versions of the publication after peer review.

- The final published version features the final layout of the paper including the volume, issue and page numbers.

Link to publication

\footnotetext{
General rights rights.

- You may freely distribute the URL identifying the publication in the public portal. please follow below link for the End User Agreement:

www.umlib.nl/taverne-license

Take down policy

If you believe that this document breaches copyright please contact us at:

repository@maastrichtuniversity.nl

providing details and we will investigate your claim.
}

Copyright and moral rights for the publications made accessible in the public portal are retained by the authors and/or other copyright owners and it is a condition of accessing publications that users recognise and abide by the legal requirements associated with these

- Users may download and print one copy of any publication from the public portal for the purpose of private study or research.

- You may not further distribute the material or use it for any profit-making activity or commercial gain

If the publication is distributed under the terms of Article $25 \mathrm{fa}$ of the Dutch Copyright Act, indicated by the "Taverne" license above, 
Nobelprijs voor Onderwijs,

Inauguratie Gerard MJ Bos

Maastricht, 7 juni 2012

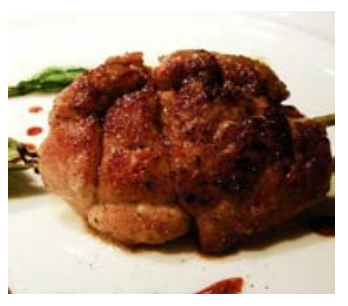

Mijnheer de pro- rector, Voorzitters en leden van het college van bestuur en raad van bestuur van het MUMC+, leden college van toezicht, collegae, familie, vrienden. Aan mij de eer om voor $U$ vanmiddag een openbare les te verzorgen vanwege mijn benoeming tot bijzonder hoogleraar interne geneeskunde, ihb onderwijs. Als oud-student aan deze faculteit ben ik opgevoed ben met het gegeven dat colleges niet echt zinvol zijn. Een college stimuleert doorgaans niet het denken van het publiek en $U$ bent waarschijnlijk niet in staat om over enkele dagen de belangrijkste boodschap van mijn oratie te reproduceren. Een deprimerende start voor $U$, maar zeker ook voor mij! Kunnen de komende minuten dan toch zinvol worden? Misschien als het mij lukt om Uw brein te activeren en $U$ bij de les te houden. Een mogelijkheid om dat te realiseren is om ook $U$ vandaag een leeropdracht te geven. Welnu, de opdracht van vandaag voor $U$ is: stuurt $U$ mij svp de voor $U$ belangrijkste conclusie van deze openbare les toe. De meest treffende zal ik dan opnemen in de electronische versie van deze oratie.

$U$ heeft inmiddels ruimschoots de kans gehad om naar deze foto te kijken. Al enig idee waar U naar kijkt? En al enig idee wat de relatie tot de titel zou kunnen zijn? Om het $U$ iets makkelijker te maken komen er twee plaatjes bij: het gerecht in ongebakken staat en de plaats waar het orgaan zich bevindt in het dier - in dit geval een kalf. Misschien helpt dit al?

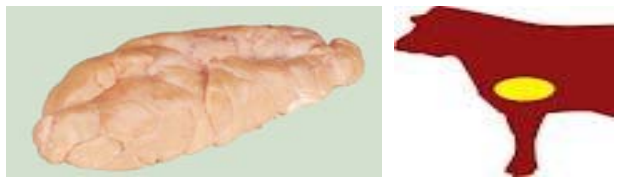

En tot slot het orgaan in tekening bij de mens:

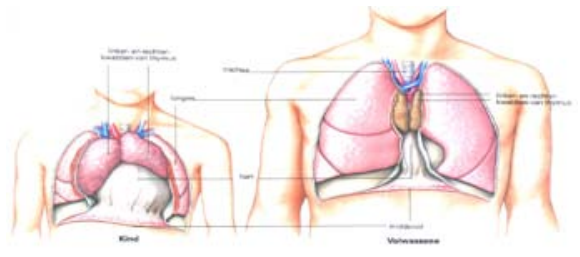

.Hhet betreft hier de thymus, ofwel zwezerik. Een orgaan dat tijdens de jonge jaren van ons leven in een groot volume aanwezig is en later in belangrijke mate in omvang afneemt. Daarom krijgt $U$ kalfszwezerik in het restaurant. Dit orgaan - de thymus - speelt een belangrijke rol bij ons afweersysteem ofwel ons immuunsysteem. Een systeem waar we de laatste jaren intensief onderzoek naar hebben gedaan. 
De organen en cellen betrokken bij ons afweersysteem kunt $U$ zien op deze plaatjes.
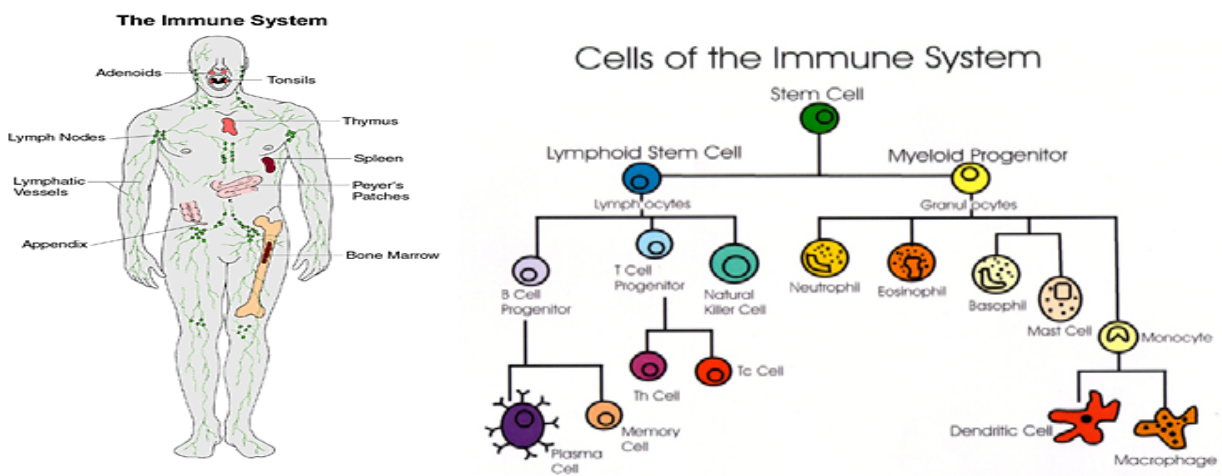

De afweercellen of immuuncellen bevindingen zich in diverse organen in ons lichaam zoals $U$ ziet op de linker tekening. De immuuncellen komen allemaal voort uit de stamcellen van ons beenmerg. Voor vandaag moet $U$ vooral de Dendritische Cellen en de T Cellen goed onthouden. Alvorens immuuncellen hun werk kunnen doen moeten ze worden opgeleid. Een belangrijke rol bij het opleiden van ons immuunsysteem - en dan in het bijzonder van de $\mathrm{T}$ cellen, speelt zich af in de thymus.

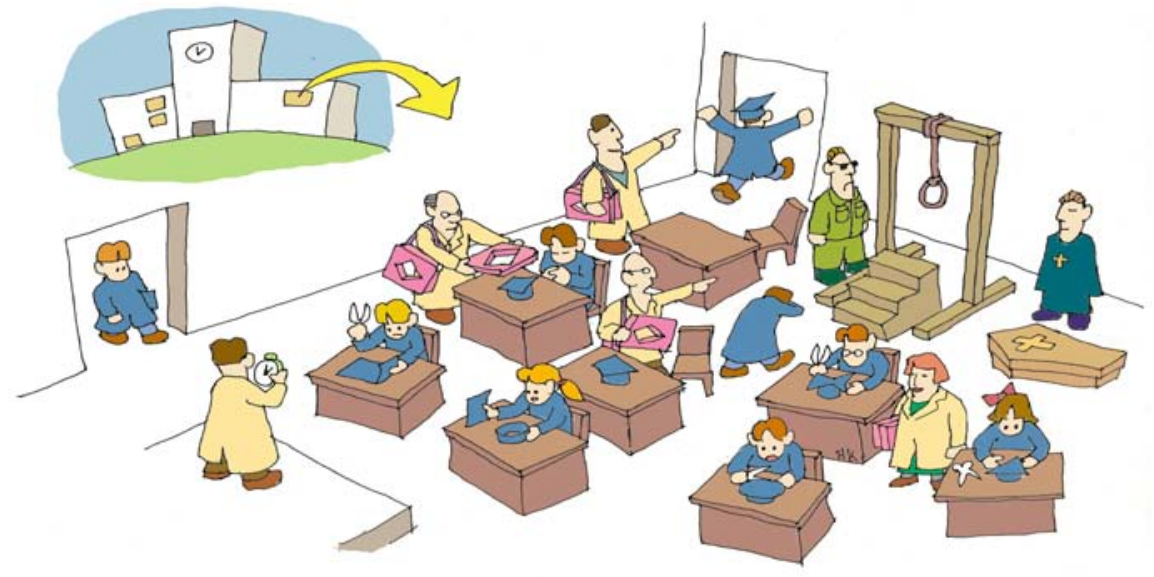

In deze cartoon wordt dit zo simpel mogelijk duidelijk gemaakt. De T cellen komen als studenten de thymus in en onder invloed van ingewikkelde processen worden ze opgevoed, geselecteerd en kunnen vervolgens als rijpe T cel dit orgaan verlaten om hun werk te gaan doen, $\mathrm{nl}$ het bestrijden van infecties.

De overeenkomst met het onderwijs - waar deze oratie over zal gaan - is daarmee voor U hopelijk duidelijk: studenten worden getraind en geselecteerd door docenten die zich in de thymus bevinden. De thymus is de medische faculteit van ons lichaam. In het medisch onderwijs staan twee vragen centraal: wat moeten de studenten leren en hoe kunnen wij dat als faculteit het beste realiseren. De eerste vraag is voor ons beantwoord in het raamplan, het wettelijk kader voor onze opleiding. In dit raamplan worden een aantal zaken duidelijk.
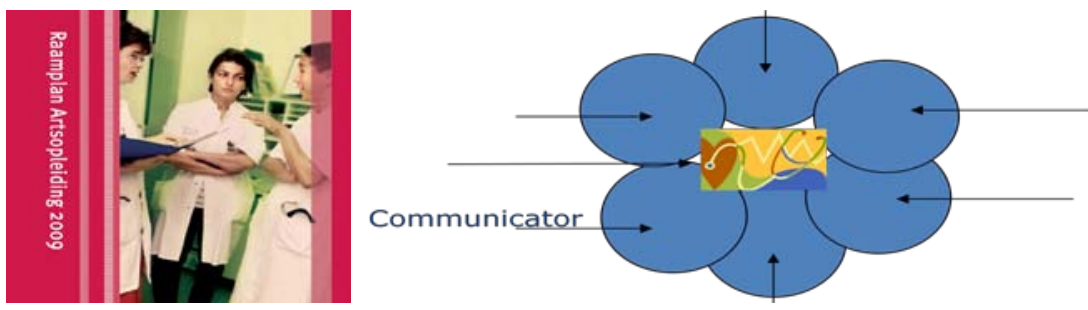
Studenten worden geachte een aantal competenties te ontwikkelen die $U$ aan de hand van deze figuur ziet weergegeven. Naast de competentie van medisch expert zijn competenties als samenwerker, communicator etc van even groot belang. Studenten worden geacht deze competenties te ontwikkelen en te demonstreren aan de hand van diverse zorgvraagstukken. Deze zijn deels weergegeven in de tabel. Het betreft min of meer zuiver medisch technische vraagstukken maar ook zorgvraagstukken van meer algemene aard.

Als we dan weten wat studenten moeten leren is vervolgens de vraag hoe we ze de benodigde expertise kunnen bijbrengen. En daarvoor is het van belang dat we enig inzicht hebben hoe dat leren van expertise eigenlijk verloopt. Even terug naar het immuunsysteem.

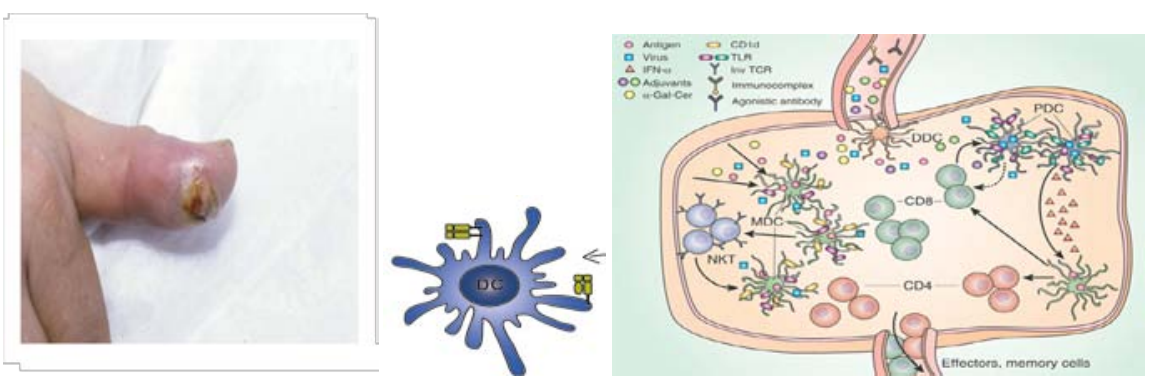

Laten we als voorbeeld nemen een wondje aan Uw duim, dat geïnfecteerd is. Bij het bestrijden van deze infectie worden dendritisch cellen en ik noem ze hier naar DCs, geactiveerd. Deze DC nemen deel van bv bacteriën die de infectie veroorzaken op en presenteren deze delen van de bacterie in de lymfklier aan de immuuncellen, met nameT cellen. Deze immuuncellen worden geactiveerd, groeien in aantal en verlaten de lymfklier om ter plaatse de infectie te bestrijden

Om hun werk goed te kunnen doen moeten DCs uit hun slapende toestand worden geactiveerd. Bacteriën, virussen en mogelijk ook kankercellen beschikken over activatie-kenmerken die de DC daadwerkelijk weten te activeren. Deze factoren functioneren als gevaar-signalen voor de DC. Alleen een goed geactiveerde DC kan aanleiding geven tot een goede immuunreactie. Wij hebben de laatste jaren veel energie gestopt in het activeren van deze DC in het laboratorium, en zijn erin geslaagd om meer optimale DC te maken. $U$ ziet dat op deze foto aangegeven, waarbij onze DC in ruim $40 \%$ van de gevallen een tumor-specifieke response geven en de controle DC dat maar in $15 \%$ van de gevallen doen. De kwaliteit van de docent bepaalt de kwaliteit van de student.
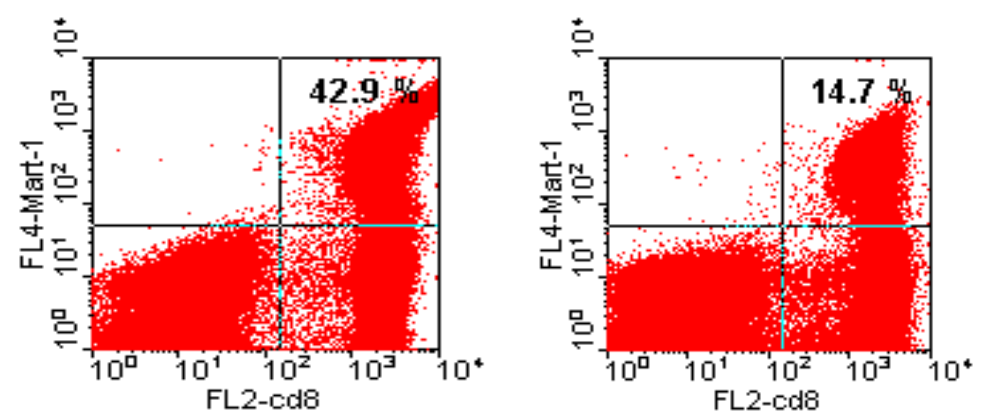

Kunnen we iets leren van het immuunsysteem? In ieder geval dat we een goede interactie tussen docenten en studenten nodig hebben, waarbij de DC symbool staat voor de docent en de T cel symbool staat voor de student.

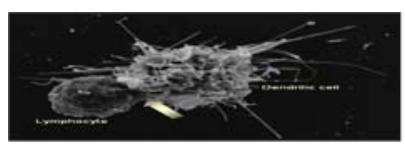

De docent en student

van het immuunsysteem 
Maar hoe dat in de praktijk gebracht? Alvorens daar vorm aan te kunnen geven is het van belang enig inzicht te hebben in de denk- en leerprocessen. En $U$ begrijpt hier begeef ik me als internist niet onderwijskundige zeer op glad ijs. Bij de start van mijn opleiding tot hematoloog - die voor een deel plaatsvond in Den Haag onder leiding van collega Hans Haak - werd ik geacht beenmergen te leren beoordelen. In het beenmerg vindt een deel van de aanmaak van bloedcellen plaats en dus wordt een hematoloog geacht hierover iets verstandig te kunnen zeggen.

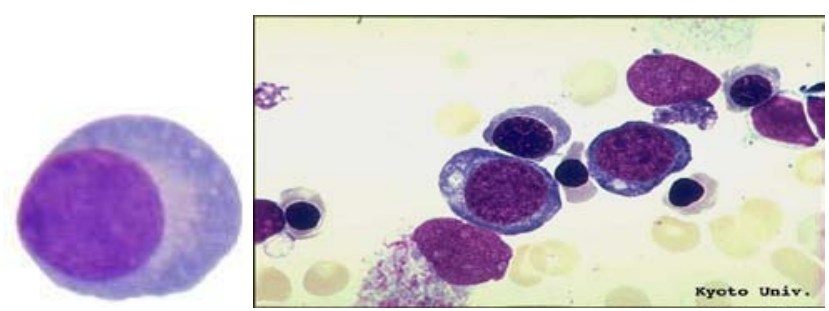

Het eerste plaatje was ongeveer het plaatje dat $U$ nu voor $U$ ziet. $U$ ziet voorlopers van rode bloedcellen en 1 cel is een witte bloedcel. Op mijn vraag waarom de ene cel nu die en de andere cel de ander was luidde zijn treffende instructie: omdat ik dat zeg, en later zul jij dat ook zo doorgeven!

Wat wist collega Haak wat ik niet wist en hoe moest ik me dat eigen maken? Wat zat er in zijn hoofd wat niet in het mijne zat? De onderwijskundige literatuur beschrijft twee systemen bij het ontwikkelen en onderhouden van kennis, weergegeven in deze tabel: Systeem 1, genoemd patroonherkening of intuitie en systeem 2 , nadenken danwel overwegen . Kenmerken van systeem 1 zijn snel, impliciet en automatisch. Kenmerken van systeem 2 o.a.: langzaam, doelbewust en systematisch.

Veronderstelling: duale denkprocessen (Prof dr JW Snoek, Dokter en Intuitie).

\begin{tabular}{|l|l|}
\hline Systeem 1 (patroonherkenning/intuitie) & Systeem 2 (Nadenken, overwegen) \\
\hline Snel & Langzaam \\
\hline Impliciet & Expliciet \\
\hline Automatisch & Doelbewust \\
\hline Associatief & Systematisch \\
\hline Reflexief & Reflectief \\
\hline Weinig inspanning & Inspannend \\
\hline Non-verbaal & Verbaal \\
\hline Parallel & Sequentieel \\
\hline Onbeperkte Capaciteit & Beperkte Capaciteit \\
\hline
\end{tabular}

Hoe gebruiken we nu deze processen in de praktijk en hoe leren we dat de studenten in het medisch domein? Een klein experiment om $U$ bij de les te houden. Hoe neemt $U$ de beslissing om een nieuwe auto te kopen. Van welke mechanismen ofwel denkprocessen maakt $U$ hierbij gebruik? Gaat $U$ eens bij uzelf na hoe het kopen van een auto bij $U$ verloopt. U krijgt van mij hiervoor enkele seconden de tijd, hetgeen mij de mogelijkheid geeft een slokje te drinken. .....

Gedachten die mogelijk door Uw hoofd gegaan zijn: ik zet alle voors en tegens van het probleem - het kopen van de auto - op een rijtje en neem dan de juiste, verstandige beslissing : maw U denkt bewust na. Ik slaap er eens rustig een paar nachtjes over en dan beslis ik: ik denk onbewust na. Ik denk helemaal niet na en ik koop gewoon de auto die me op het eerste gezicht het beste bevalt: ik vertrouw op mijn intuitie. Wat is nu wijsheid om te doen? 


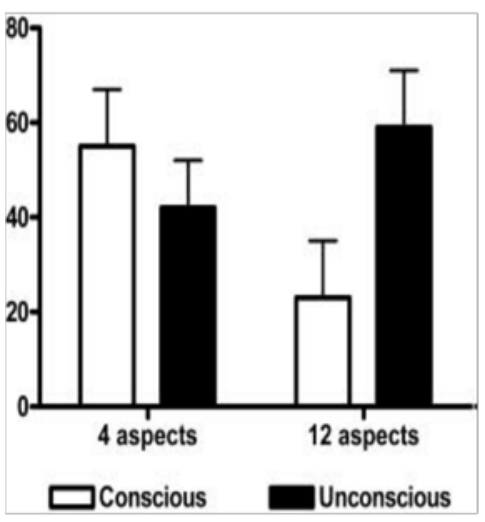

Het kiezen van een auto

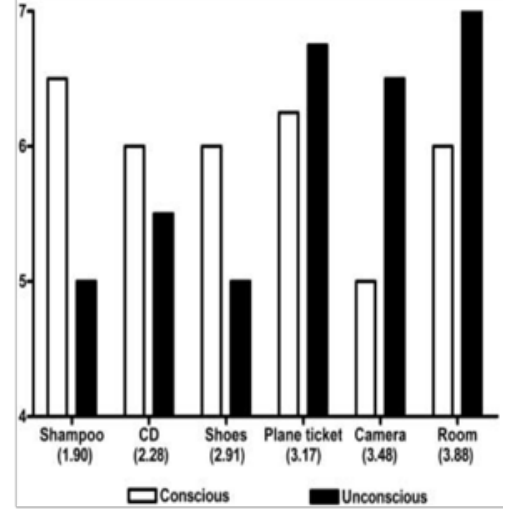

Het kiezen van andere producten

AP Dijksterhuis et al. Science 311, 1005 (2006)

Dijksterhuis en collegae hebben daar onderzoek naar gedaan ( gepubliceerd in het toptijdschrift Sience, 2006). In het linker deel van de figuur betrof het de keuze uit auto's met slechts 4 kenmerken, waarvan sommigen gunstig andere ongunstige eigenschappen betreffen. $U$ moet denken aan verbruik, veiligheid, topsnelheid etc. In het rechter deel van de figuur betreft het 12 kenmerken van auto's met weer wisselend positieve of minder gunstige eigenschappen. Proefpersonen werden gevraagd goed over de kenmerken na te denken dan wel werden gevraagd om een irrelevante puzzel op te lossen en dus onbewust tot een keuze te komen. Laat de resultaten even rustig op $U$ inwerken. Misschien verrassen ze $U$. Kort samengevat: zijn er weinig kenmerken waarover U kunt nadenken, dan maakt nadenken niet al te veel uit. Nadenken is misschien iets beter, dan niet nadenken. Maar zijn er veel opties waar $U$ over na kunt denken dan helpt dat nadenken helemaal niet. Een puzzel maken in plaats van nadenken leidt tot de aanschaf van de betere auto!. De ondezoekers maken met dit onderzoek aannemelijk dat een onbewust denkproces bij meer complexe materie tot een beter resultaat leidt dan bewuste denkprocessen. Gelden de zojuist genoemde observaties ook voor beslissingen binnen het medische domein, een auto kiezen is immers iets anders dan een medische diagnose stellen. Dezelfde onderzoekers onderzochten dit bij studenten psychologie, gepubliceerd in 2010. De studenten psychologie werden uitgenodigd om over twee complexe patiëntproblemen na te denken. Ook hier werden studenten gevraagd om of bewust na te denken over alle aspecten van de casus dan wel na het lezen van de casus werden ze verzocht een irrelevante puzzel op te lossen. $U$ ziet de resultaten in bijgaande figuur: opnieuw blijkt dat bewust nadenken niet leidt tot het vaker stellen van de goede diagnose. De linker kegel, onbewust, versus de rechter kegel, bewust, toont bij beide problemen betere resultaten.

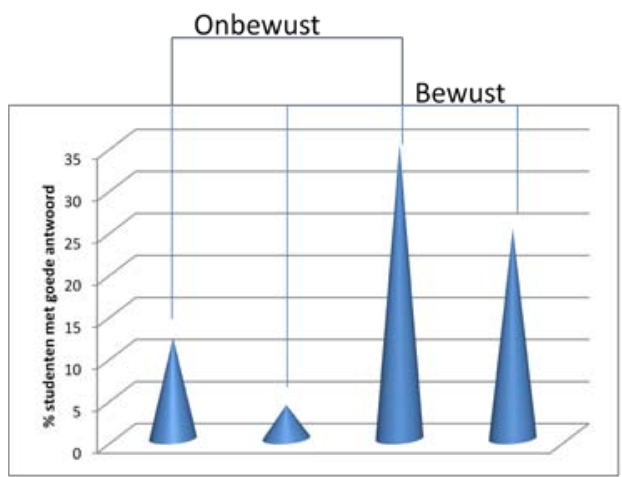

Casus 1

Casus 2

De auteurs komen tot dezelfde conclusie: bewust nadenken leidt niet tot betere resultaten ook niet als studenten om medische diagnoses gevraagd wordt. Ik weet niet hoe het $U$ hier vergaat, maar ik wordt toch een beetje onrustig bij het idee dat dokters beter niet nadenken bij serieuze problemen. Min of meer tegelijkertijd 
- we praten hier ook over 2010 - kwam ook een publicatie uit van de groep van Henk Schmidt, velen van U hier goed bekend omdat hij in de beginjaren van de organisatie hier gewerkt heeft, alvorens naar Rotterdam te verhuizen. Zij hebben aan zowel medisch studenten in het $4^{\mathrm{e}}$ jaar van hun studie (dus nog weinig klinische ervaring) en aan specialisten in opleiding tot internist 12 problemen voorgelegd, 6 makkelijke en 6 moeilijke.

Ook om te onderzoeken of bewust nadenken helpt.

Aan $U$ de vraag: wat verwacht $U$ van het intuïtieve oordeelsvermogen van studenten en meer ervaren specialisten in opleiding tav eenvoudige en complexe casuïstiek. Helpt nadenken of kunnen student en arts inderdaad beter even met de secretaresse kletsen en koffie halen?

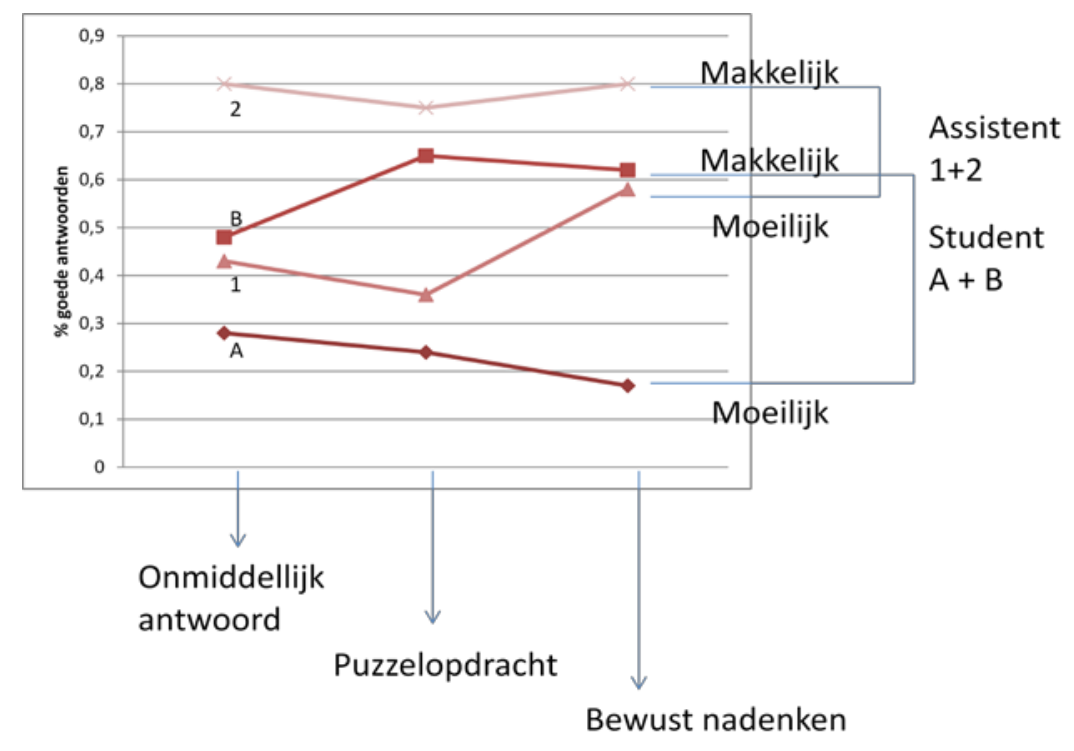

De resultaten van dit onderzoek ziet op in deze ingewikkelde figuur, waar ik $U$ graag door heen zal helpen Twee lijnen ( $A$ en $B$ ) betreffen de studenten, onervaren, en twee lijnen (1+2) zijn de meer ervaren specialisten in opleiding. Specialisten in opleiding stellen intuïtief vaker de goede diagnose dan studenten. Bij de makkelijke problemen scoren assistenten (punt 2) beter dan studenten (punt B). Bij de moeilijke problemen is dat ook zo (punt 1 versus punt A), waarbij opvalt dat intuïtie voor beide groepen in minder dan de helft van de gevallen tot het goede antwoord leidt. Er moet dus iets gebeuren in het belang van de patiënt. Vervolgens blijkt dat specialisten geen baat hebben bij het nadenken over eenvoudige problemen (de bovenste lijn), maar wel zeker baat hebben bij het nadenken over complexe problemen (de een na onderste lijn). Voor studenten is dit anders: zij hebben mogelijk baat bij het nadenken over eenvoudige problemen - hoewel een irrelevante tijdsinvulling - puzzelen - ook betere resultaten geeft - maar kunnen met complexe problemen ook door na te nadenken niet uit de voeten. Sterker nog, de kans op een goed antwoord neemt af! Wat leren we hiervan: vooral dat studenten met te complexe problematiek zeker niet uit de voeten kunnen. Er is om hen betere klinische beslissers te maken, nog een lange weg te gaan.

Hoe nu goed onderwijs te organiseren. Hoe ontwikkelen we bij studenten zowel de intuïtie, nodig om eenvoudige problematiek beter te kunnen hanteren en hoe leren we ze beter klinisch redeneren bij meer complexe situaties. De liefhebbers verwijs ik graag naar een zeer lezenswaardig boek van Robert Hogarth, educating intuition .

Hij geeft aan dat de leeromgeving waarin intuïtie het best ontwikkeld kan worden stoelt op twee kenmerken: feedback en de consequentie van het maken van fouten. $U$ ziet dat uitgebeeld op deze figuur. 


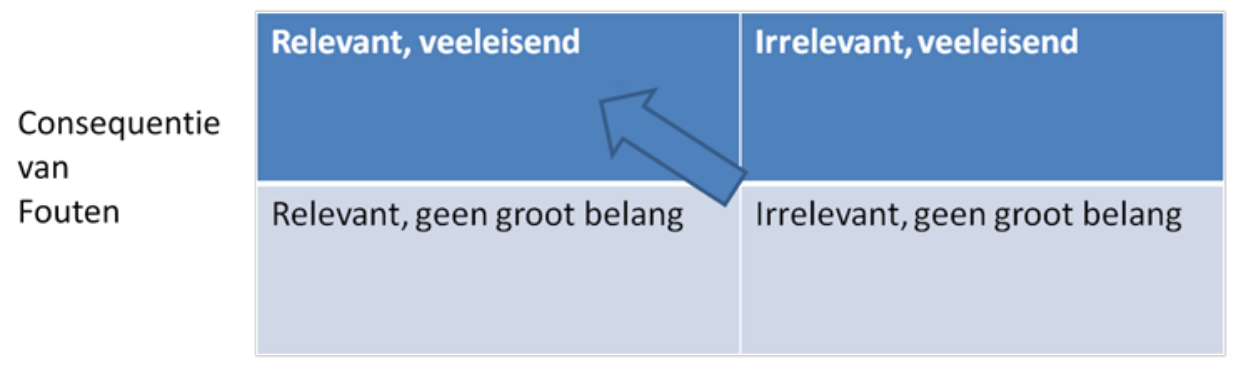

Kwaliteit van feedback

Op de $x$-as de relevantie van feedback, op de y-as de relevantie van fouten. Als een fout resultaat van klinisch redeneren geen enkele consequentie heeft - een papieren casus bv - zal het leerrendement minder zijn. Voor een optimaal leerrendement moeten studenten worden opgeleid in een leeromgeving waarin ze goede feedback krijgen aan de hand van authentieke, leerzame taken waar fouten op de loer liggen.

In Nederland hebben wij de medische faculteiten, waar artsen worden opgeleid, zodanig geordend dat studenten doorgaans beginnen met onderwijs in de schoolbanken, geleidelijk aan worden meer praktijk situaties aangeleerd, om vervolgens in de klinische praktijk een echte expert te worden. In Maastricht speelt het eerste deel van de trainingen zich overwegend in de eerste fase af (de bachelor fase) en de laatste 3 jaar van de opleiding betreft de masterfase, die in Maastricht volledig uit praktijkstages bestaat. Over deze Masterfase wil ik het verder met $\mathrm{U}$ hebben.

Hoe hebben wij de masterfase ingericht? Een schematisch overzicht treft $U$ aan op de gepresenteerde figuur. De student volgt een aantal stages zoals chirurgie, psychiatire etc. De stages duren 5 tot 10 weken en binnen de stages is de student vaak aanwezig op verschillende afdelingen.

U ziet dat aan het uitgewerkte voorbeeld van de interne geneeskunde.

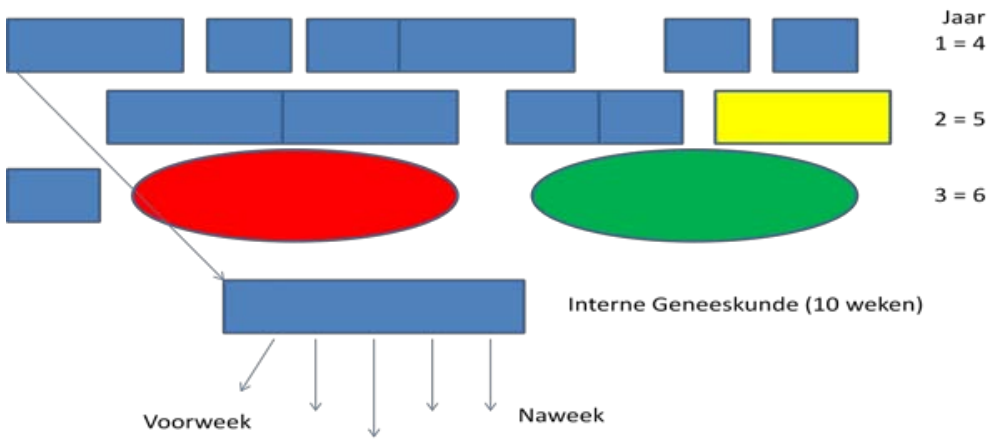

Deze stages verzorgen wij voor ruim 300 studenten per jaar, dus ruim 1000 studenten in Maastricht in de masterfase. Een activiteit die wij alleen maar kunnen realiseren dankzij de hulp van zeer velen die veel enthousiasme voor onderwijs hebben: ziekenhuizen tot in Brabant, huisartsen tot in Zeeland en diverse zorginstelling verspreid over zuid-Nederland alsmede partners in het buitenland dragen in belangrijke mate bij aan de opleiding van onze studenten. Studenten zijn overwegend tevreden over de stages. Maar toch denken we dat het beter kan! En voor een organisatie die leading in learning als haar pay-off gebruikt is dat dan ook een grote uitdaging.

Ik ga even terug naar de dendritische cel: Bij deze figuur ziet $U$ dat ook voor de activatie van de DC geldt dat het nog beter kan. Door aan de activatie-cocktail een extra stof toe te dienen (de rechter balk) gaat de DC nog meer interleukinen - weergeven op de y-as - produceren en kunnen ze de immuuncellen nog beter activeren. 
Een observatie waarvoor onlangs een patent is ingediend en waarvoor we nu in de opstartfase zijn van een biotech-bedrijf, om de dendritische cellen te gebruiken voor het ontwikkelen van een vaccin tegen kanker. De nieuwe CEO heeft net vorige week deze uitdaging geaccepteerd. Het opstarten van een bedrijf is overigens geen sinecure. Want waar het het doel van artsen en onderzoekers is om patiënten beter te maken zijn er bij de businessmensen ook andere doelen: financiële waarde creëren en buy outs voorbereiden zijn voor mij althans nieuwe termen. Een interessante kruising van verschillende werelden.
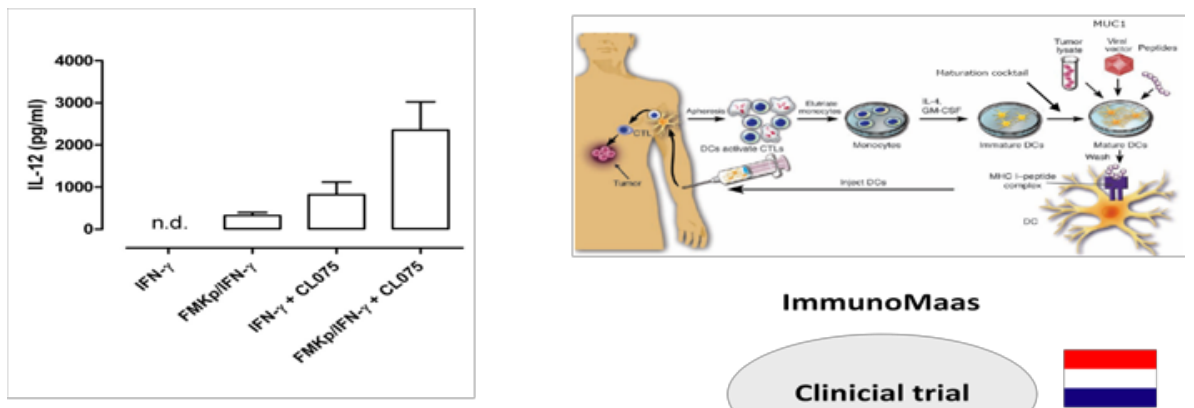

ImmunoMaas

Clinicial trial

Een vaccin tegen kanker zoals we ons dat voorstellen is weergegeven in de figuur. Cellen afkomstig uit de patiënt worden in het laboratorium gekweekt tot DC, beladen met stukjes van de tumor, geactiveerd en vervolgens bij de patiënt teruggespoten om het immuunsysteem gericht tegen kanker te activeren.

Onze belangstelling om een vaccin op de markt te brengen geeft mij de mogelijkheid om een uitstapje te maken naar de kosten en organisatie van de zorg. De laatste dagen weer volop in het nieuws. Wij geven nu ongeveer $13 \%$ van ons Bruto Nationaal Product uit aan de zorg en als de ontwikkelingen zo doorgaan zal dat stijgen naar $30 \%$. Niet onmogelijk - we kunnen dat betalen - maar dan is er geen geld meer voor JSF vliegtuigen, misschien niet zo erg, maar ook niet meer voor vakanties voor een groot deel van onze bevolking. Je kunt een euro immers maar 1 keer uitgeven.

Er is recent een vaccin met behulp van DC op de markt gekomen voor prostaatkanker. Met het volgende resultaat: patiënten leven gemiddeld 4 maanden langer.

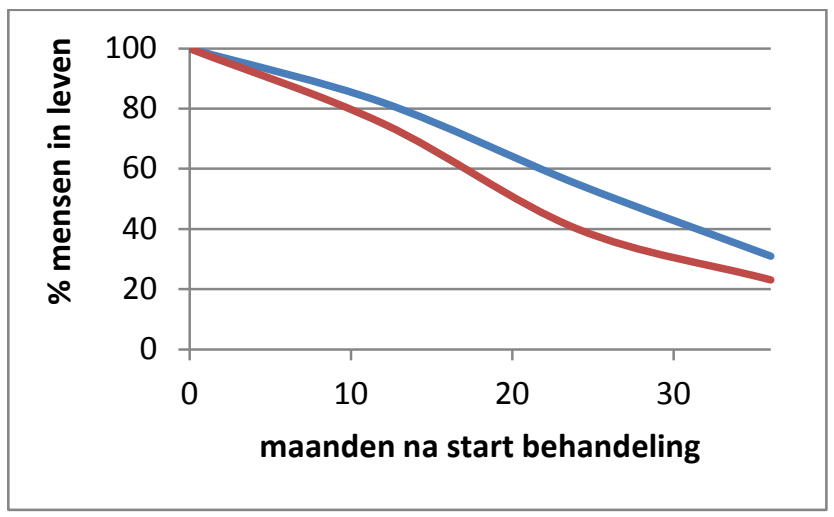

Dit overlevingsvoordeel is mooi en voldoet aan de criteria wanneer ook wij in Nederland behandelingen accepteren en bekostigen. Ook de meeste patiënten zullen voor de behandeling kiezen, zeker als de bijwerkingen gering zijn zoals bij deze vaccins. De behandeling kost echter wel 60.000 euro! In die zin is het 
goed om de waarde van deze behandeling eens in een ander perspectief te zetten. De patiënten waren allemaal ongeveer 70 jaar toen ze aan deze behandeling begonnen. En $U$ ziet wat een winst van 4 maanden op deze tijdsas betekent. We kunnen en zullen met zijn allen de discussie aanmoeten of we deze kosten (60.000 euro) willen financieren in de afweging met andere doelen om ons geld te besteden.

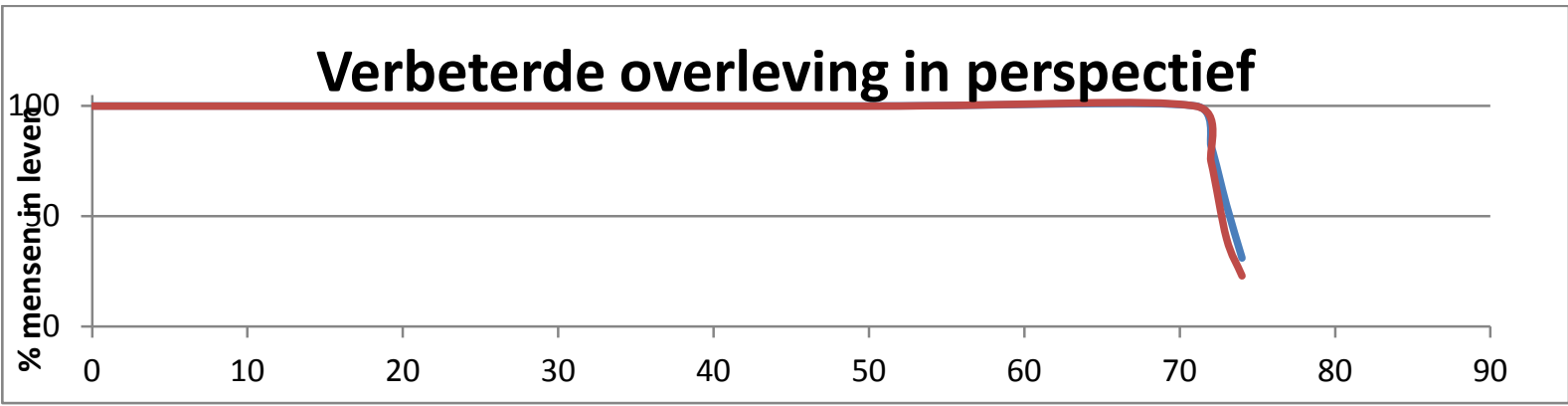

Kunnen we dan kosten reduceren door de zorg beter te organiseren? Over hoe de zorg te organiseren is er een levendig debat gaande, zich toespitsend ogenschijnlijk op de rol van wel of niet marktwerking. Ik val hierbij graag terug op de filosoof Kolakowski die mi het dilemma goed heeft verwoord als het gaat om de inrichting van onze maatschappij:

- Socialistisch, omdat de onmogelijkheid van een utopische samenleving geen alibi is voor sociale laksheid. Maar ook:

- Liberaal omdat een alomvattende organisatie van de maatschappij tot stagnatie en onderdrukking leidt.

Hoe realiseren we met deze uitgangspunten een rechtvaardig zorg-systeem? Graag maak ik hier gebruik van de analyse van John Rawls uit de beginjaren 70 van de vorige eeuw. Hij formuleerde de voorwaarden voor rechtvaardigheid als volgt :

1. Er moet sprake zijn van gelijke rechten

2. Er moet sprake zijn van gelijke kansen

3. En als derde introduceerde hij het concept van het ongelijkheidprincipe.

Met name dat laatste begrip heeft waarschijnlijk enige toelichting nodig. Ongelijkheden zijn - aldus Rawls noodzakelijk en toegestaan mits ze in ieders voordeel werken. Met andere woorden: sociale en economische ongelijkheden moeten en kunnen ingezet worden mits ze tot het grootst mogelijke voordeel strekken van de minst bevoorrechte leden van de samenleving. Dit concept lijdt tot de meest doelmatige en doeltreffende organisatie van onze samenleving. Geen marktwerking dus waar winstmaximalisatie het belangrijkste doel is, maar wel financiële prikkels aldus Kolakowski en Rawls.

Maar hoe goed en doelmatig we de zorg ook organiseren: de belangrijkste discussie zal blijven: wat willen we betalen aan het einde van het leven waar we het grootste deel van de kosten besteden. Dit is een maatschappelijk discussie die niet - en zeker niet alleen - op het bordje van artsen kan liggen. Dat zou tot willekeur in behandelingen leiden. Het lijkt me zeker wel een taak om onze artsen op te leiden in de zin dat ze de verantwoordelijkheid nemen om patiënten en publiek te informeren over de impact van hun activiteiten, inclusief de manier waarop ze een bijdrage gaan leveren aan een zo doelmatig mogelijke organisatie van de zorg. Preventie zal in het debat over kosten overigens maar zeer beperkt helpen. Preventie vertraagt het optreden van ziekten - zeer de moeite waard - maar voorkomt meestal niet het ziek worden. Een enkele uitzondering zoals roken en vaccinatie tegen baarmoederhalskanker daargelaten. Succesvolle preventie is niet een oplossing voor de kosten in de zorg, zoals nog wel eens wordt gesuggereerd. Voldoende stemadvies lijkt me voor 12 september. Voor de mensen die onlangs op de PVV stemden - en dat waren er in deze regio nogal 
wat - en overwegen dat opnieuw te doen is het misschien goed om nog op te merken dat Kolakowski is geboren in Polen.

Terug naar de praktijk van het onderwijs. Waar schieten onze stages zo mogelijk te kort, en waar kan het beter? Rene Stalmeijer van onze faculteit heeft recent onderzocht welke aspecten van werkplaatsleren van belang zijn. De meest belangrijke randvoorwaarde voor een goede stage blijken actieve participatie en goede feedback, zoals door Hogarth al aannemelijk was gemaakt. En helaas, zo weten we ook uit onze eigen faculteit, is goede feedback geven het zwakste punt van het onderwijssysteem.

Wat gaan we aan ons onderwijs optimaliseren zodat betere feedback gerealiseerd kan worden? Op deze figuur ziet $U$ wat de geplande veranderingen zijn.

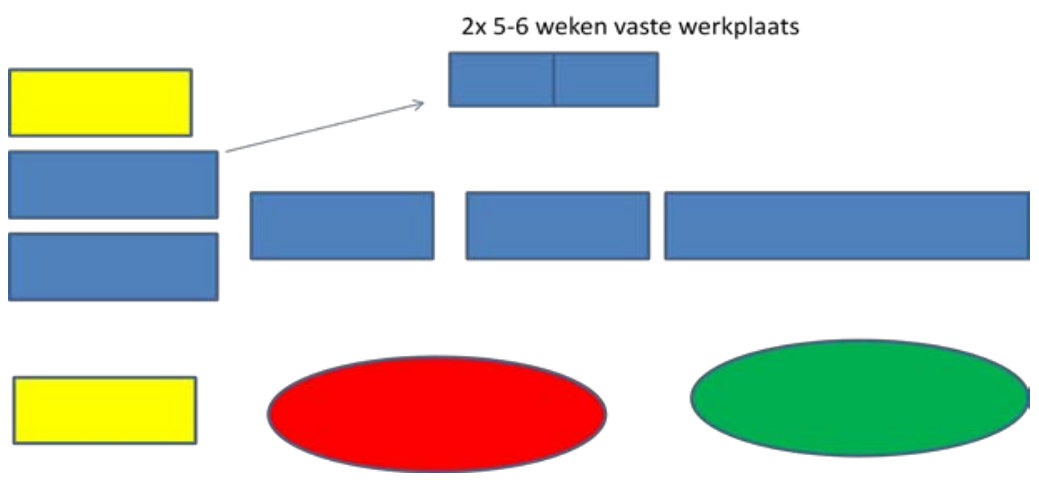

We gaan met name minder maar langere stages aanbieden, geordend in clusters. Op het oog niet spectaculair maar voor het veld toch al een belangrijk kantelpunt. Belangrijkste verschil is dat studenten in het nieuwe model minimaal 5 tot 6 weken op 1 werkplek zullen zijn. Het verschil zit dan ook niet alleen in de lengte van de blokken (nu clusters genoemd) maar vooral in wat de studenten binnen de clusters gaan doen. Niet meer meekijken op diverse afdelingen, een weekje hier een weekje daar, maar een vaste werkplek, met een goed omschreven taak in het team. Actieve participatie in het team wordt uitgangspunt. Dat zal binnen de zorginstellingen, daar waar dat voor huisartsen al veel gewoner is, toch een belangrijke omwenteling zijn. Niet meer een anonieme student die een weekje meekijkt, maar een student die 6 weken blijft en die je echt moet laten participeren. Dan is het toch ook wel handig als je haar of zijn naam kent! We gaan proberen betere randvoorwaarden voor betere feedback te realiseren.

Naast de andere inrichting van de stages zullen we ook - onder leiding van Marjan Govaerts - ons toetssysteem aanpassen. Studenten zullen niet per stage of cluster een afrondende toets hebben, maar de toetsing zal longitudinaal zijn. De student neemt daarbij de feedback van de eerste stage mee naar de volgende stage. We spreken dan ook niet meer over feedback maar uitsluitend over feedforward. Het toetsen is gericht op optimaliseren, het verder verbeteren van de kwaliteiten van de student.

Behalve de interactie tussen student en docent zijn er meer factoren die het succes van leren bepalen.

Terug naar de immunotherapie. Het is mooi dat we met behulp van onze docent, de dendritische cel, de andere immuuncellen kunnen activeren en tot actie over kunnen laten gaan. Maar laat het doel van deze actie - in ons geval de kankercel - dit zo maar gebeuren? De kankercel bevindt zich in een omgeving die hem onkwetsbaar lijkt te maken voor aanvallen van buitenaf, zoals het immuunsysteem. Een stof waarmee deze kankercel dat bv lijkt te doen is prostaglandinen. Wij onderzochten de rol van prostaglandine op de interactie tussen DC en immuuncellen. En als ik wij zeg dan bedoel ik met name Jeanin van Ellsen die - onder leiding van Wilfred Germeraad en Joris Vanderlocht en met de niet aflatende steun van Birgitte Senden, onlangs op dit onderzoek promoveerde. 
Door het toevoegen van prostaglandines aan het testsysteem verliezen immuuncellen het vermogen om kankercellen te doden. Hoe meer prostaglandines in het testsysteem - op de x-as naar rechts - hoe minder

dode kankercellen - op de y-as naar beneden.

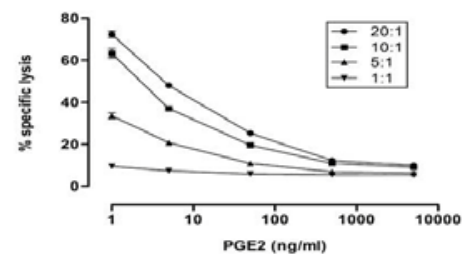

Wat zijn de prostaglandines van het onderwijssysteem?

1) Tijd

2) Ruimte (Fysiek)

3) Aantallen studenten (in relatie tot 1,2 ).

Uit evaluaties blijkt dat met name tijd een beperkende factor is voor kwaliteit. Artsen hebben het druk, de poli is overvol en het begeleiden van de student schiet er bij in. Onderwijs kost tijd, en dus geld. Een groot probleem is tevens ruimte. Om studenten zelfstandig te laten werken is ruimte nodig. Door de komst van een praktijkassistente blijkt er in de praktijk van de huisarts geen extra kamer meer te zijn, er worden geen studenten meer aangenomen voor een stag. En ook in de ziekenhuizen is er chronisch ruimte tekort, waarbij maatschappen die het goed voor hebben met het onderwijs vaak tevergeefs aankloppen bij de raden van bestuur. In de bouwplannen is veelal niet voorzien in extra ruimten voor stagiaires. Ook hier speelt geld een belangrijke rol.

Tot slot het aantal studenten. Er is een maximaal aantal studenten dat organisaties aankunnen. En dat maximale aantal is van direct belang voor de kwaliteit. Te veel studenten is synoniem aan mindere kwaliteit, zo blijkt uit alle evaluaties.

Kunnen we het aantal studenten dan reduceren? In een tijd dat van ons gevraagd wordt om juist meer artsen op te leiden is dat een onmogelijk idee. Maar er zijn misschien wel andere mogelijkheden: maatwerk in plaats van een confectie-pak. De geneeskunde-opleiding staat in het continuüm van levenslang leren. Misschien moeten we dat al jaren geconstateerde concept meer serieus nemen. Deze figuur geeft het perspectief aan van de opleidingsduur in relatie tot de totale tijd van expertise-ontwikkeling.

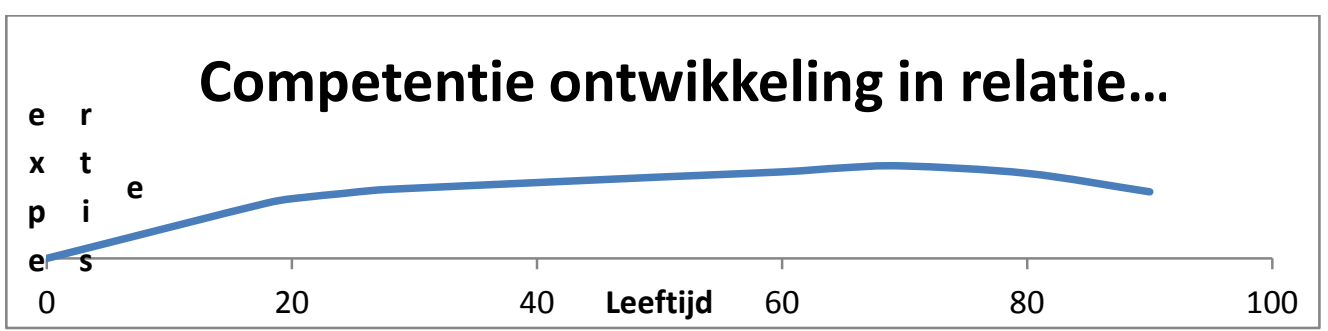

Het is ondoenlijk en onnodig om alles in korte tijd de revue te laten passeren met als ambitie dat de medisch student als basisarts alle competenties volledig onder de knie heeft. Immers er volgt voor praktiserende artsen daarna altijd een vervolgopleiding en zelfs of misschien wel juist na de vervolgopleiding staat het leren niet stil. Voor de student is het van belang dat hij/zij voldoende competenties heeft ontwikkeld om de vervolgopleiding met succes te kunnen afleggen. ledere vervolgopleiding zal daarbij andere eisen stellen en andere accenten leggen. Waarom moet de basisartstraining voor iedereen het zelfde zijn en voor iedereen 6 jaar duren? De vraag stellen is deze misschien ook wel beantwoorden. In schema: er is een korte maar - vanwege de actieve participatie - zeer doeltreffende brede oriëntatie voor alle studenten waarna er een beroepsoriëntatie volgt. 
Gesteund door mentoren en toekomstige opleiders wordt er een op maat vervolgprogramma gemaakt. Ik leen hier het idee van collega Maessen van de cardiothoracale chirurgie die het toepast in zijn opleiding: een vroege stage met een specifieke vraagstelling maakt het mogelijk om verwachtingen van student en opleider- bv tav technische vaardigheden - in kaart te brengen. Is de student niet handig genoeg, kan hij beter een andere discipline kiezen. Dit maatwerk zal voor een substantieel deel van de studenten de opleiding kunnen verkorten en ook de vervolgopleiding efficiënter kunnen maken, als we de totale opleiding zien als een continuüm. Hier kunnen we tijd winnen en ook efficiënter met onze opleidingscapaciteit omgaan, zonder dat we inboeten aan kwaliteit. Daarmee voldoen we tevens aan een maatschappelijke vraag. Immers de opleidingen zijn duur en het duurt langs voordat de basisarts als medisch specialist beschikbaar komt. Ik denk onnodig lang.

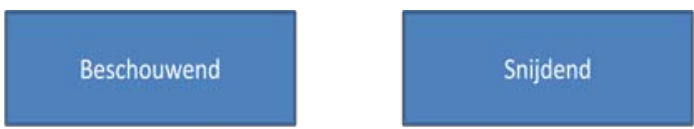

$1^{\mathrm{e}} \mathrm{lijn} / \mathrm{soc}$ geneeskunde

Beroepsorientatie

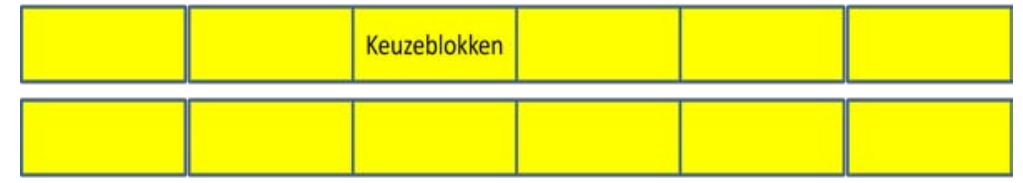

Aantal keuzeblokken wordt flexibel, in overleg met opleider vervolgopleiding en mentor

Ik zie de manager financiën al denken: lagere aantallen met een hogere intensiteit: wie gaat dat betalen? Daar zullen inderdaad nieuwe modellen voor ontwikkeld moeten worden. Het publiek mag van de instellingen echter verwachten dat zij de taken op gebied van zorg, onderwijs, opleidingen en onderzoek in goede samenspraak regelen. In het ideale model zouden mi de conglomeraten van zorginstellingen - in ieder geval de ziekenhuizen - onder 1 raad van toezicht moeten vallen, die er op toe ziet niet of de taken worden uitgevoerd, maar hoe goed de combinatie van taken worden uitgevoerd. Onderwijs hoort daar nadrukkelijk bij. Het staat immers in de eed van Hippocrates: het onderwijzen van studenten is onderdeel van de taak van artsen.

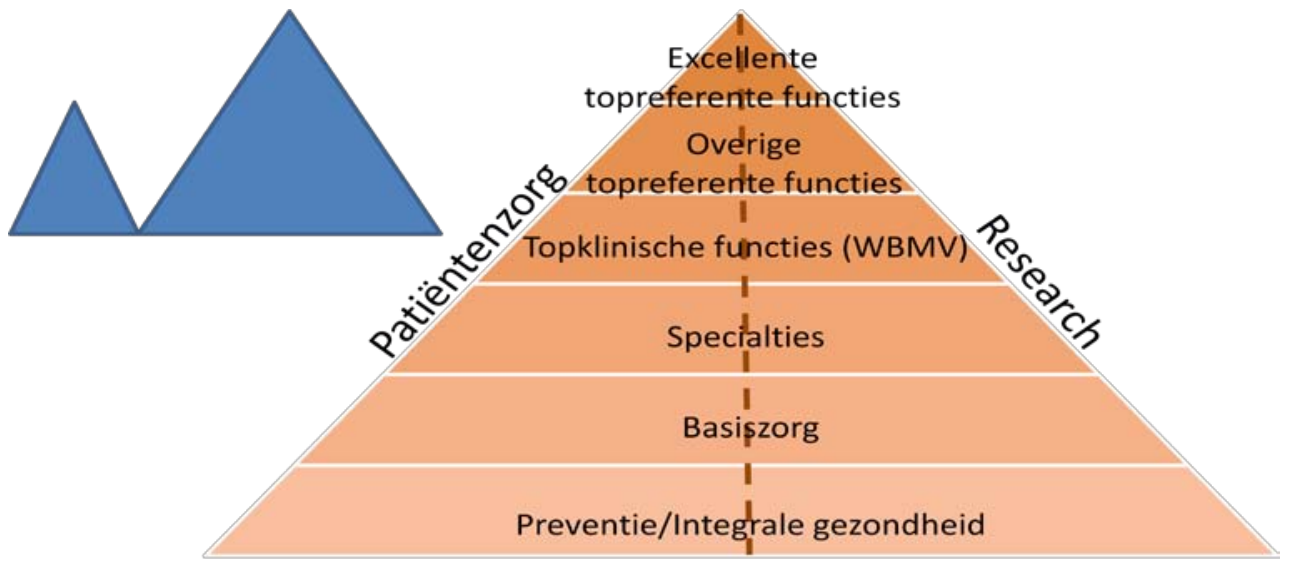

Onderwijs \& opleiding 
Het is verheugend om te zien dat onze RvB de samenhang onderkent van zorg, opleidingen en onderzoek, getuige deze recent door hen verspreidde figuur. Waarbij misschien opmerkelijk, maar mi terecht is gekozen voor onderwijs \& opleiding als basis in een academische setting. Een figuur die als kader dient om vorm te geven aan center of excellences. Dhr Peters, Voorzitter van onze RvB, heeft mij enkele weken geleden uitgedaagd om tijdens deze inauguratie vooral met praktische, werkbare suggesties te komen. Welnu: ik doe een poging. Laten we - voordat we over excellentie praten - vooral zorgen dat de basis van onze organisatie staat. Dat is eenvoudig te realiseren door een budget voor academische ontwikkelingen op basis van de klinische omzet te genereren. Voor een bepaald percentage van dit budget zijn de professionals zeer goed in staat om hun academische taken vorm te geven. In termen van een pizza: zorgen voor een goede bodem. En het extra's is voor wat er op komt. De hoogte van de piramide wordt immers bepaald door de breedte van de basis! En de goede pizzeria - gaat $U$ het maar bij $U$ zelf na - herkent $u$ aan de kwaliteit van de bodem, en niet aan de kwaliteit van de salami.

Overigens denk ik dat wij zelf - artsen en onderzoekers - zeker kunnen bijdragen aan het vergroten van de middelen voor de taart en niet alleen maar lijdzaam moeten toezien in tijden van bezuinigingen. Onze pizzabodem voor het onderzoek is de laatste jaren o.a. gerealiseerd door mensen uit de directe omgeving die het belang van het onderzoek naar kanker inzien en daar graag een bijdrage aan willen leveren. Zonder iemand te kort te willen doen noem ik hier graag en met veel respect de naam van Henk Stienstra. Hij heeft ons onderzoeksteam de laatste jaren geweldig ondersteund en gemotiveerd. Zonder deze steun zouden wij weinig dendritische cellen hebben kunnen onderzoeken. Zou ik hier waarschijnlijk niet hebben gestaan. Een samenwerking gebaseerd op vertrouwen.

Het heeft ons vooral ook gemotiveerd om een eigen fondsenwervende organisatie te starten, waarvan $U$ hier het logo ziet. Een fondsenwervende organisatie die niet alleen als doel heeft om fondsen te werven maar ook onze organisatie zichtbaar te maken naar onze omgeving, om deuren en ramen open te zetten. Te streven naar een community. Een initiatief door velen inmiddels gesteund en gedragen, waarvoor dank.

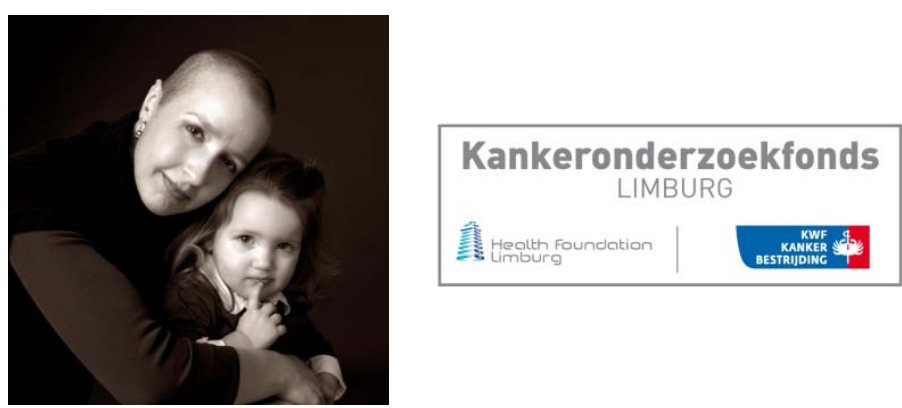

Ik hoop oprecht dat het de insteek van dit fonds zal worden dat met de middelen de samenwerking in onze organisatie - maar zeker ook met alle partners in de regio - kan worden geoptimaliseerd. En dat tussen onderzoekers niet het recht van de sterkste zal gelden. Maastricht is echt te klein voor onderlinge concurrentie . We zullen ons als professionals moeten uittillen boven de korte termijn outputparameters.

Tot nu toe heb ik vooral gesproken over de organisatie en de grote wereld daarom heen. Nog weinig over de rol van de student zelf. Kunnen we de studenten zelf een meer belangrijke rol geven? En kunnen we dat als organisatie dan faciliteren.

Weer even terug naar de immunotherapie: het immuunsysteem heeft vele cellen die betrokken zijn bij uiteindelijk haar belangrijkste taak: het bestrijden van infecties. De dendritische cel heeft $U$ al ontmoet evenals de T cel. Het immuunsysteem kent ook nog Natural Killer cellen die bij bestrijden van vooral virusinfecties van belang zijn. En ook - waarschijnlijk zeer bruikbare wapens worden in de strijd tegen kanker. Zo liet onze onderzoeksgroep - met Lotte Wieten en Michel van Gelder als stuwende krachten - zien dat we met deze Natural Killer cellen in proefdieren borstkanker kunnen genezen -en er zijn ook zeer hoopvolle resultaten bij de 
ziekte van Kahler, een beenmergziekte. In dit panel ziet $U$ de resultaten bij muizen met borstkanker. Daar waar muizen met chemotherapie en bestraling allemaal dood gaan overleven vrijwel alle muizen die voldoende, geselecteerde Natural Killer cellen van een donor hebben gehad (de bovenste twee groepen in de figuur).

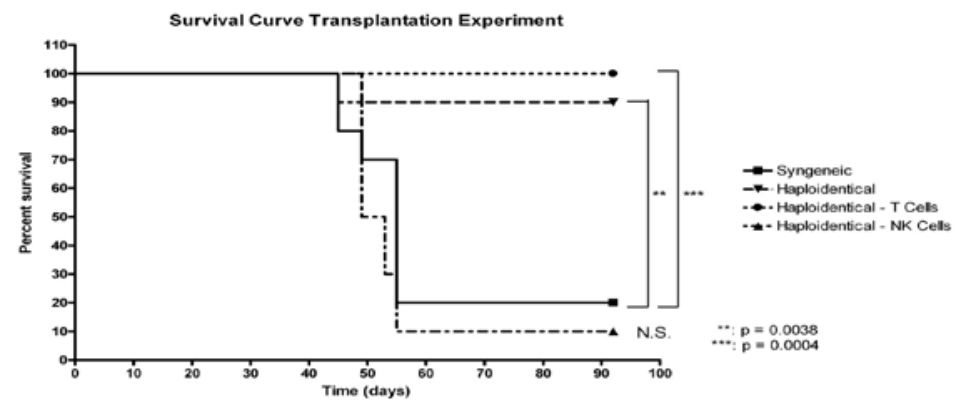

Als we de overlevingscurve bij mensen daadwerkelijk kunnen ombuigen zou dat natuurlijk fantastisch zijn. Overigens is ook deze therapie niet goedkoop. Het kweken van deze cellen in voldoende aantallen zal al snel 25.000 euro per persoon gaan kosten. Maar dan is het goed om ons te realiseren dat als we mensen kunnen genezen dure therapieën goedkoop blijken te zijn. Dan zal celtherapie goedkoper zijn dan cholesterolremmers per gewonnen levensjaar.

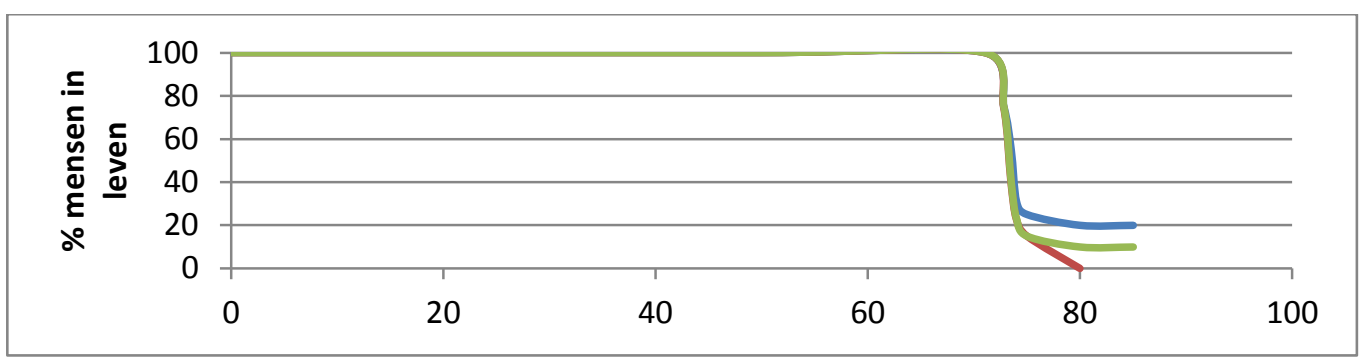

Wat nu blijkt is dat alle genoemde immuuncellen elkaar zeer kunnen versterken. Natural Killer cellen kunnen Dendritische cellen activeren en andersom. En NK cellen kunnen tevens een bijdrage leveren aan de activatie van $T$ cellen. Mocht $U$ hier meer over weten dan verwijs ik $U$ graag naar het genoemde artikel.

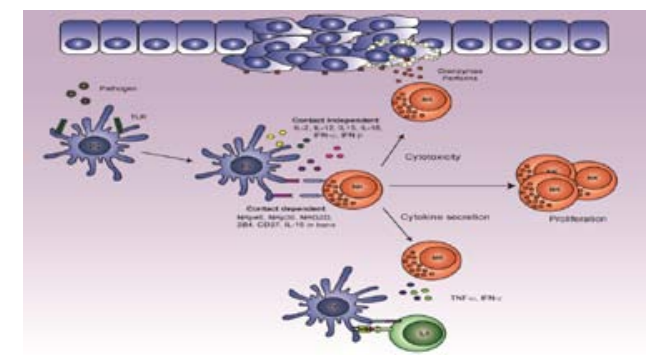

Kunnen studenten elkaar ook helpen? Hiertoe zijn we enige tijd geleden in de bachelorfase een onderzoek gestart dat uitgevoerd wordt door Juliette Hommes. Uit een eerste analyse blijkt dat in ieder geval voor studenten de mate van interactie met anderen relevant is voor hun studieresultaten. 


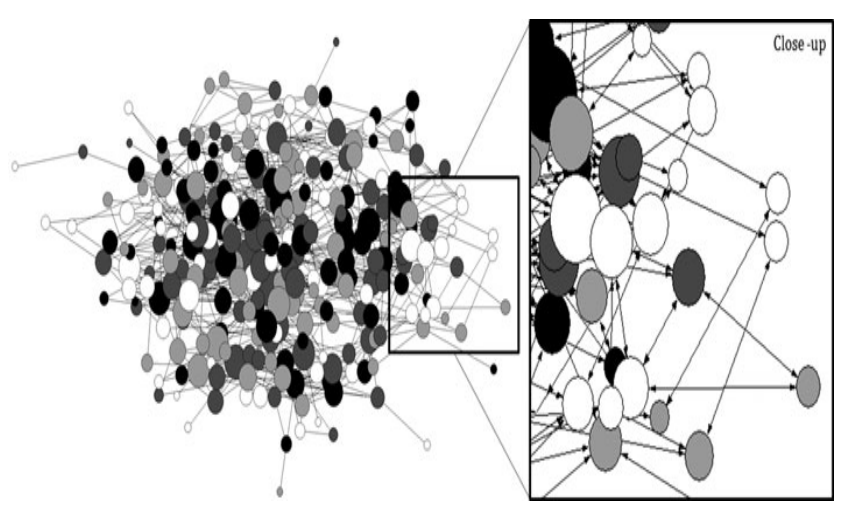

Studenten- hier weergegeven in de vorm van bolletjes - met een groter aantal sociale contacten blijken in een diverse opzichten beter te functioneren, en ook mogelijk betere studieresultaten te vertonen. Het onderzoek nu loopt naar het effect van het bewust creëren van sterkere netwerken bij studenten. Als een netwerk van studenten van belang is in de bachelor fase, zullen we het ook kunnen inzetten in de masterfase. Een onderzoeksvoorstel voor de SWOL - een organisatie die het onderzoek aan onze Universiteit ondersteunt - is hiervoor in de maak. Elkaar stimuleren en helpen kan - aldus het immuunsysteem - niet anders dan goed zijn.

Dames en Heren, het ontwikkelen van onderwijsprgramma's is een uitdaging. Maar er is ook - voor zover ik de onderwijskundige literatuur kan overzien - de constatering dat we nog over relatief weinig kennis beschikken om het onderwijs gericht op competentieontwikkeling in goede banen te leiden.

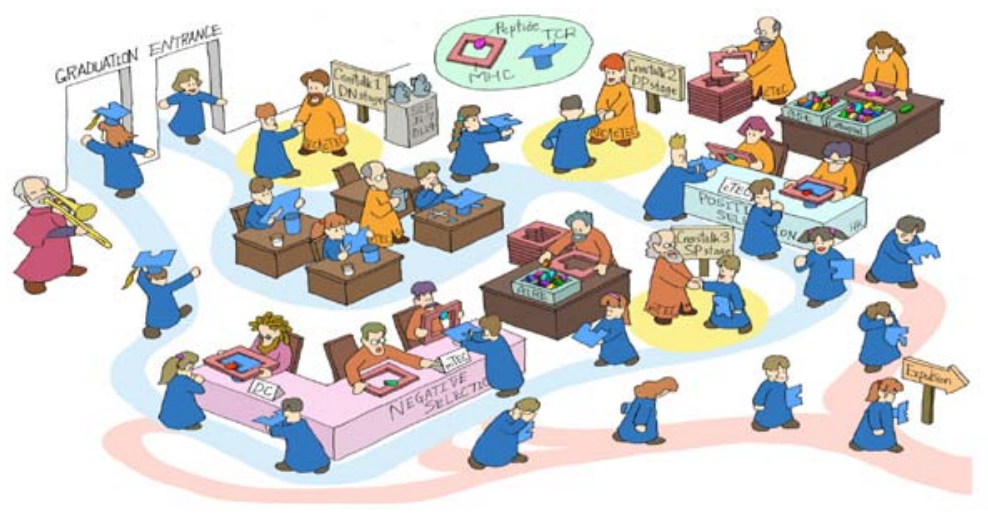

De processen in de Thymus blijken veel ingewikkelder dan in de eerste cartoon is aangegeven en onze kennis is niet compleet. We weten echter nog veel minder van competentieontwikkeling in het (medisch) onderwijs. Kijken wij bv naar het aantal publicaties tav werkplaatsleren tov die van dendritsche cellen en T cellen dan is het verschil in aantal zeer opmerkelijk, terwijl het werkplaatsleren al 200 jaar oud is en het immuunsysteem veel korter bestudeerd wordt.

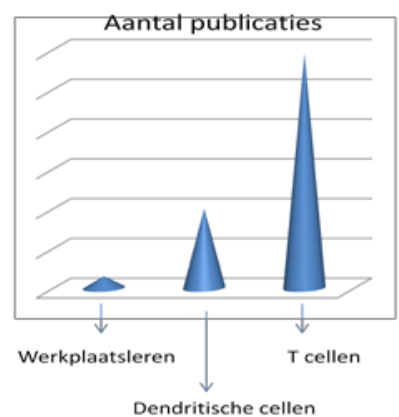


Mij als niet onderwijskundige valt het daarbij tevens op dat harde eindpunten in het onderwijskundige onderzoek veel minder aan de orde zijn. Toch denk ik dat we voor de harde eindpunten in de studies niet moeten weglopen. Ook het reguliere medisch onderzoek zit vol met confounders - verstorende factoren - die voor de resultaten van het onderzoek nopen tot een voorzichtige interpretatie. Complexiteit van de leeromgeving zou onderwijskundigen niet moeten weg houden van gewaagde studies, die wij als artsen in de praktijk vervolgens kunnen helpen interpreteren en implementeren. Een uitdaging om hier de komende jaren gericht onderzoek naar te doen, waarbij we als het aan mij ligt de hulp moeten inroepen van disciplines die voor zover ik het nu kan overzien- nog beperkt bij het ontwikkelen van ons onderwijs betrokken zijn. We hebben in Maastricht een belangwekkend Brains Unlimited programma. Gaat de anatomie en fysiologie van het brein ons helpen bij de optimale leerprocessen? Ik verwacht van wel.

Tot slot: ik ben $U$ nog de oplossing van de titel verschuldigd. Vorig jaar gebeurde er iets heel bijzonders in de geschiedenis van de Nobelprijs. Deze werd namelijk uitgereikt aan een persoon die vlak daarvoor was overleden. Slechts enkele uren na zijn overlijden werd bekend dat het comité voor de Nobelprijs Geneeskunde deze prijs had toegekend aan Ralph Steinman. Steinman was de ontdekker van de dendritische cellen, in 1973. Ik heb hem een enkele keer kunnen spreken. Een inspirerend man. Gezien de rol van de denritische cellen in het immuunsysteem en wat we daar in conceptuele zin van kunnen leren kreeg hij de prijs dus ook een beetje voor onderwijs. Steinman overleed aan kanker. Ook nadat hij zichzelf een vaccin met dendritische cellen had toegediend, voor zover we weten zonder effect. Als het onderzoek naar onderwijs dezelfde vlucht wil nemen dan het onderzoek van het immuunsysteem - en ik denk dat de maatschappij er redenen voor heeft dat te willen - dan zal er voor het onderwijs misschien ook wel een prijs met een zelfde groot prestige moeten komen om onderwijs de plaats te geven die het maatschappelijk verdient. Een uitdaging voor onze organisatie - leading in learning - dat bij het Nobelcomité te bewerkstelligen.

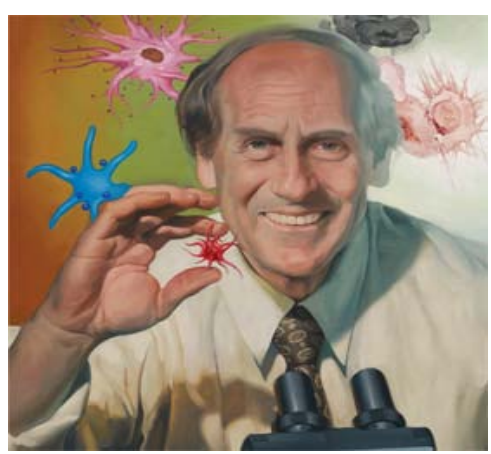


Het is gebruikelijk om een oratie te beëindigen met een dankwoord. Met het risico dat velen die letterlijk en figuurlijk aan de wieg van deze benoeming hebben gestaan ook genoemd hadden moeten worden, terwijl ik ze nu niet noem. Ik ben $U$ niet vergeten!

Allereerst de Universiteit en MUMC en de daarbij meest direct betrokkenen: Prof Dr Albert Scherpbier als decaan en Prof Dr Martin Paul als voormalig decaan en nu Voorzitter van het College van Bestuur hebben, samen met de leden van de benoemingscommissie, Prof Dr Coen Stehouwer, hoofd van de afdeling interne Geneeskunde, Prof Dr Harry Schouten, hoofd van onze onderafdeling hematologie en Prof Dr Frans Ramaekers als directeur van het onderzoeksinstituut GROW deze benoeming mogelijk gemaakt. Niet nadat wijlen Prof Flendrig mij twee keer heeft aangenomen voor de opleiding tot internist. En ja, om twee keer te worden aangenomen moet je ook een keer ontslagen worden. Bij mijn promotie stonden Prof Peter van Breda Vriesman en Prof Reneman als promotoren aan de basis van mijn wetenschappelijke carrière. Gesteund door Dr Gerard Majoor en Prof Dr Dick Slaaf als co-promotoren. In de tijd dat je nog een sigaartje kon roken op de werkkamer ter bespreking van de resultaten. Het aantal mensen in de ziekenhuizen en instituten (in totaal 7(die mede verantwoordelijk waren voor mijn opleiding tot internist en hematoloog alsmede de diverse leidinggevenden van de onderzoeksinstituten waar ik me verder kon bekwamen in de immunotherapie, zijn te veel om op te noemen. We zouden vandaag niet aan een wijntje toekomen. Mijn dank gaat natuurlijk uit naar alle collega's die nu binnen het onderzoekslaboratorium de klinische afdeling, en het onderwijsinstituut mijn leven soms moeilijk maar meestal heel veel makkelijker maken.

En met Uw goed vinden bewaar ik mijn dankwoord voor de mensen die mij persoonlijk zeer dierbaar zijn voor een ander moment op deze dag.

Ik heb gezegd. 
Naschrift:

De belangrijkste conclusies ingestuurd door enkele toehoorders van deze openbare les.

- $\quad$ De zwezerik moet je kloppen, dan veroudert deze niet (Tai-tji wijsheid ; Mevr Mulder-Bos geb. 1920).

- Geen zwezerik meer eten (M Jager)

- Docenten die dendritische cellen van studenten kweken en injecteren in patiënten zijn slimme artsen! (E vd Ven)

- Je herkent een goede pizzabakker aan de bodem! Hier blijft het helaas de discussie of dat hard en knapperig is of juist dik ( $M$ van Everdingen).

- Onderwijs, onderzoek en zorg zijn sterk verweven en daarom is het noodzakelijk om samen te werken (in en over de sectoren) om effectiever onze doelen te bereiken (W Germeraad).

- Het immuunsysteem en onderwijs (cq de overdracht van kennis en vaardigheden) is complex en multifactorieel bepaald en beiden aan het onderbewustzijn onderhevig (K. Kleinen)

- $\quad$ Een metafoor is een belangrijke tool bij kunst der onderwijzen. (K. Kleinen)

- De kwaliteit van een opleidende omgeving bepaalt de mate van succes van hetgeen dat cq de persoon die is opgeleid (U Mark)

- Adaptatie aan veranderende omstandigheden en continue leren is een voorwaarde voor vooruitgang en verbetering van systemen en mensen (U Mark)

- De scholing van T cellen als leidraad voor je oratie vond ik treffend voor een bijzonder hoogleraar Interne Geneeskunde in het bijzonder Onderwijs, een mooie vergelijking met "leading in learning" de kreet van de Um-Mumc. Ik vraag me wel af of bewust dan wel onbewust het, Immunologisch, zwezerikje niet iets te vroeg geofferd is. Nu lopen we het risico dat we enkel nog het beleg van je onderwijs-pizza kunnen aanschouwen. Blijf als culinair expert erop letten dat de bodem steeds voldoende Immunologische bestanddelen zal bevatten! (Hub en Jose, paranimf).

- $\quad$ Er valt nog heel wat te leren over het (medisch) leren (B Jongen). 